\title{
O PROTAGONISMO DE ISÓPODOS TERRESTRES NO ENSINO DE CIÊNCIAS: DESCRIÇÃO DE DIFERENTES ABORDAGENS PEDAGÓGICAS
}

\author{
Silveira, L.H.R. ${ }^{1}$; Kenne, D.C. ${ }^{1,2} \&$ Gomes, K.M. ${ }^{2, *}$ \\ ${ }^{1}$ Universidade Federal do Rio Grande do Sul (UFRGS), Campus do Vale, Laboratório de Ecologia Química \\ e Quimiotaxonomia. \\ ${ }^{2}$ Universidade Federal do Rio Grande do Sul (UFRGS), Campus do Vale, Laboratório de Carcinologia. \\ *Autor correspondente: k.marttinez@gmail.com
}

\begin{abstract}
A utilização de crustáceos em aulas práticas de ciências no ensino básico se restringe a ilustrações da diversidade e a interações desses invertebrados com o meio ambiente. Além disso, quando presentes na didática, os crustáceos são representados por espécies marinhas e, muitas vezes, destoando da realidade do aluno. Assim, este trabalho propõe a utilização de organismos conspícuos e presentes no cotidiano da maioria dos alunos, como os tatuzinhos-de-jardim, para a elucidação de conceitos fundamentais na disciplina de ciências. As abordagens pedagógicas propostas foram direcionadas ao $7^{\circ}$ e $9^{\circ}$ ano do ensino fundamental de uma escola da zona rural de Gravataí - RS. As espécies utilizadas foram Armadillidium vulgare, Atlantoscia floridana, Porcellio scaber e Balloniscus glaber. Os tópicos trabalhados foram: (1) a construção do pensamento científico, (2) compreensão das variáveis que descrevem o movimento retilíneo uniforme e (3) as relações entre os atributos ecomorfológicos e a conquista do ambiente terrestre pelos oniscídeos. No tópico "1" foram desenvolvidas atividades que envolveram experimentos de preferência alimentar, fotoperíodo e percepção da presença e ausência de abrigo pelos isópodos terrestres, além da adaptação experimental propostas pelos alunos para adequar-se a disponibilidade de recursos oferecidos pela escola. O tópico «2» envolveu a elaboração de uma pista de corrida de tatuzinhos-de-jardim para a visualização prática dos parâmetros "distância" e "tempo" no cálculo da velocidade média. Por fim, o tópico «3» promoveu questionamentos quanto às adaptações dos oniscídeos aos diferentes ambientes terrestres ocupados, abordando as estratégias adotadas por esses organismos que refletem à categorização dos isópodos em grupos ecomorfológicos. As didáticas propostas melhoraram o interesse e a participação dos alunos, ampliando a capacidade crítica e de questionamento. A partir da reflexão do docente, alinhada ao pensamento construtivista de Piaget e sociointeracionista de Vygotsky legitimou-se não só a importância do conhecimento cognitivo do aluno, como também a oportunidade de ampliação de seus conhecimentos na área da zoologia aplicada.
\end{abstract}

Palavras-chave: isópodos terrestres, ensino, ciências, educação, crustáceos. 